\title{
Climate Change: Our Rush to Extinction or Victim of Our Own Success?
}

\author{
Vinay Kumar Upadhyay \\ Presently working at Central Pollution Control Board \\ Zonal Office: Vadodara, Gujarat, India \\ E-mail: vinay0408@gmail.com
}

\author{
Kamna Sachdeva (Corresponding author) \\ Department of Natural Resources, TERI University \\ 10 Institutional Area, Vasant Kunj, New Delhi, India
}

Tel: 91-11-2612-2222Ｅ-mail: kamna.sachdeva@teri.res.in

Received: March 26, 2012 Accepted: April 23, 2012 Published: May 14, 2012

doi:10.5296/emsd.vli1.1554 URL: http://dx.doi.org/10.5296/emsd.vli1.1554

\begin{abstract}
The paper has adopted a theoretical approach to explain the problem of climate change and its connectivity with the life style philosophy. The issue of climate change here has been discussed through the lens of modern and traditional theories. The study has emphasis on the need of policy evaluation before suggesting the solutions to the problem. Solutions in the broad framework of triple bottom line: social, economic and environmental domains have been provided. Study also correlates the responsibility of different groups of society to reduce the pace of our extinction.
\end{abstract}

Keywords: Climate change, Responsibility, lifestyle philosophy, climate refugees, Climate adaptation 


\section{Introduction}

The science underlying the activity of green house gases was noticed in 1820 by Joseph Fourier and Tyndall in 1859 (Fourier Joseph, 1878; Tyndall John, 1861). Never could have Fourier imagined that what he observed more than a century ago will rebound back to haunt the humanity. Climate change is a reality now. Anthropogenic contributions and ipso-facto certainties of climate change are unequivocal. The growing body of evidences: Svante Arrhenius (Arrhenius S, 1896) highlighted the role of $\mathrm{CO}_{2}$ in atmospheric warming in 1896 and in the early $20^{\text {th }}$ century. E.O Hulburt and Stewart Callender supported the Arrhenius theory (Hulburt E.O, 1931; Callendar G.S, 1938). Finally the assessment of James Hansen in 1988 ascertained the role of humans in already measurable global climate change (Hensen J, 1988). IPCC the most authoritative body, mandated by WMO and UNEP, in its first report (1990) noticed the ill effects of GHGs. In its later reports IPCC became far more vociferous in ascertaining the fact that anthropogenic emissions has turned into a Frankenstein. The science underpinning the climate change is indubitable now. Though the IPCC has been mandated to be scrupulously policy neutral, it has been urging nations to act with expediency to deal with the scenario, which would worsen with the passage of time, apathy, indifference and inaction (IPCC, 1996; IPCC, 2007).

\section{Theory and philosophy}

Ethics and decision making in climate change purview: atmosphere is considered to be a global common and every living individual has equal right to share it. Ecological footprint as a tool can be utilized to arrive to a resource sharing criterion. A crucial distinction of survival emission footprint, sustainability emission and luxury emission footprint should factor in while considering the sharing of the universal common. When survivality is in question, the present generation of poor countries and larger section of population of many underdeveloped and developing countries toiling with the hunger pangs and malarial deaths, cannot figure in the concerns of the future descendants. Taking a bio-centric philosophical positioning, when other living organisms like animals are also included, the sharing formula can still be far perplexing. Now this cannot be answered fully by traditional policy approach.

Meanwhile, certainties to clinch a globally negotiated deal to garner a policy for the climate change are remote, given the protractions of the political willingness to arrive to an agreement. The climate may not sustain waiting for the result of tedious international negotiations. The better way ahead for the poor and developing countries is work toward adaptation, of the consequences of the inadvertent climate change. The best policy prescription for adaptation is development. Limited access to capital weakens the institutional infrastructure and thereby technological advancements to cope. The economic empowerment will help them to entrench themselves against many odds .The under-developed and developing society overall becomes better equipped to deal the thorny situation.

\subsection{Lifestyle Philosophy}

Lifestyle Philosophy: "Let him feed on butter though he runs in debt;" is what Cārvāka (Cārvāka philosophy is also known as Lokāyata and is set out in the Barhaspatya sutras) has to say regarding the lifestyles one should adopt (Radhakrishnan, $S$ and Moore, C, 1957). This 
school of thinking has some equivalence in the utilitarian approach introduced by the philosopher John Stuart Mill (1806-73) and advocated by Bentham (Mill J.S, 1864).

Immediate self gratification is what the Cyrenaic hedonism proposes. "Eat, drink and be merry, for tomorrow we die" and to vouch for it with little concern for future (Voula T, 2004). Self gratification while advocating indulgence is often at the expense of someone else. Such lifestyle ushers in the "tragedy of commons" (Garrett Hardin, 1968).

\section{Discussion}

Need for action: our rush to extinction. Need is to mainstream these identified solutions into future policies.

\subsection{Apocalyptic View}

Evidences are there when an entire organisimic species was wiped out from the face of the earth, many civilizations were lost, and owing reasons ranging from the possible meteoritic damage, algal toxins, to a drastic change in the environment. The mass-extinction at the end of the Permian 251 million years ago occurred from a sudden rise in concentration of carbon in the atmosphere (Raup and Jr. Sepkoswki, 1982., Benton, 2003., Hallam and Wignall, 1997). The looming Climate change scenario presents the same predicament to the survival of the modern human-kind and significant others. When civilization is at stake urgent action is imperative. The longer we procrastinate, the tougher it will be.

\subsection{Intergenerational Equity}

The principle of the intergenerational equity tells us that there should be parity in terms of the quality of the atmosphere which we bequeath to our future generation and they should be not at the climatic odd when they come into being.

\subsection{The climate refugees}

These people are the peacetime evacuees who are actually bearing the brunt of the climate change. These forced migrations occur when the adaptation strategies fails to deliver the desired outcome. Discussion on the issue of forced migration is relatively at nascent stage, though IPCC had predicted in 1990 that greatest human related impact due to climate change will be mass migration (IPCC, 1990 and 1997). It will be used as one of the adaptation means to combat climate change (Lovell 1997). Forced migration has many other lateral dimensions attached to it (Labor mobility, Poverty, Human trafficking, Social security) and the need is to address these issues along with concrete international immigration polices. The intensity of mass migration in different geographical settings, more or less, is dependent on mitigation and adaptation policies of the local government. To address the issue of mass migration effectively we need to:

Define the status of climate refugees and recognize extreme climate scenario as important driver of mass migration under international law. The United Nations'1951Convention and 1967 Protocol relating to the status of refugees need to be more accommodating (appendix1).

Develop policies embarking upon tribulations of internal mass exodus and the trans-boundary 
migration. The impact of displacement in both scenarios is nonetheless similar, so should be the policy treatment.

\subsection{Responsibility}

The quanta of green house gases pumped into the atmosphere, which till date continues to be spewed unabated, besides the thermal inertia, will cause inexorable temperature rise. Nature is constrained to ricochet with fury in form of drought, floods, storms, hurricanes and typhoons and other hazards. Rights and responsibilities among nations in consonance with their capabilities create an ethical dilemma.

\subsection{Developed countries}

Historically they are the largest emitters of the green house gases, starting with advent of coal fired engines concomitant with the industrial revolution. One may be pardoned for the ignorance, but after the IPCC report on the cause-effect relationship of anthropogenic emissions and the climate change it may be regarded as a willful act. Hence the ethical responsibility is fixed.

These large emitters of green house gases are being laggard at the climate change negotiation (US has not the ratified the Kyoto protocol) (Zedillo, 2008), the international treaty formulation is thereby taking the beating. Public opinion back there is also ignorant about the human induced climate change, only a fraction agrees to the fact that anthropogenically induced climate change is a reality. The situation gets exacerbated with business house spreading misinformation; the government is not pressed into action.

\subsection{Developing nations and others}

About $80 \%$ of the world's population belongs to this group who has a large chunk of population surviving in full glare of poverty. Their living condition requires subsequent improvement. Moreover, international negotiations on climate change are often Barmecidal to the developing and poor economies. Development therefore becomes the leitmotif of any policy document for these countries. Developing countries treading on the path of economic growth have to bear in mind that growth rate of building more than one power plant a week is farfetched in seeking their developmental goals. Countries capable of finances must avoid any competition between adaptation and mitigation pathways. For economically poor countries adaptation is the only way out of the climate change quagmire as they lack the financial muscle to work for the mitigation strategies.

\subsection{Individual responsibility}

As stakeholders we can all exercise our power (as shareholders) to diminish our imprint on nature. One cannot move away invoking the call for collective responsibility. Rather, reduce the individual carbon footprint by bringing lifestyle to a more sustainable mode and avoid straining the earth's carrying capacity. Create a moral levee for oneself by not eating more of the pie. 


\section{Decision making: The way forward}

Subsequent to decades of denial, we now have realized the extent and dimensions of problem. The solution can't be one but diverse, multi layered and touching upon all the segments of the problem arena. We have reached to the point where one's ruse will not solve the purpose but simultaneously all the yards should be applied to deal with the situation.

\subsection{Social}

How much of environment protection and or use is rather a basic fundamental social question. Treading the Rawlsian welfare model (Ball, 1987), taking care of the weakest of the society, sustainable development is a suggesting answer. Such an inquiry also requires a political willingness to global social welfare more than the Pareto and "compensation principle".

\subsection{Economic}

In economics, decision-making cost benefit analysis and cost effectiveness analysis is most useful tool, but is closely related to utilitarian function. Besides, the Environment Kuznets curve the telltale for the impact of growing income (per capita GDP) and the corresponding environmental impact, narrates that with the growing income there are some associated ecological destruction but as the income grows further the claim for better environment is upped. But this does not stand generalized, as at many places the curve does not holds good. Now nature is not going to loan anyone its services in eternity. Tipping point or not, it still demands back some debt servicing. Hartwick's rule can explain the issue of non-renewable resources use and sustainability (Hartwick, 1997).

\subsection{Environment (sustainable development)}

Aldo Leopold asserted that the health of the ecosystem is what should be of prime significance (Errington, 1948). He further argued that an environmental policy is right if it preserves the integrity of the ecosystem and wrong if it does not. For him use of natural resources is acceptable but not the over-use. Limits to growth is one of the most talked about topics and endowed with a finite natural resources the humanity conjures upon this serious impediment to overcome (Meadows et al, 1972). The fossil fuel based economy of today need to find its earlier alternative. Oil production is sooner or later going to see its "Hubbert's Peak" (peak of production) and then decline (Cavallo, 2004). If renewable energy is one step forward then there is need to repeat the Neolithic solar energy revolution, which converted / harvested the solar energy useful to humankind, this achievement was called agriculture.

\subsection{Geo-Engineering}

Technological fix may offer some respite but a large scale geo-engineering again conjures upon the same ethical dilemma meddling into the affairs of nature. Ethical acceptability of intentional climate change is less for the risk associated with it largely unknown (Dale 1996).

\subsection{Ethical dialogue (Habermas)}

The aim of the dialogue is not necessarily to achieve agreement, but rather to find a way of living with each other's disagreement in peace and find pragmatic ways of dealing with each 
other in practical matters even if disagreements still existed (Johansen, 2007).

\subsection{Energy policy}

Must look thoroughly into the industrial energy policy, for instance and likewise, out of the total estimated 250 million tonnes of direct $\mathrm{CO}_{2}$ emissions from the industry in India in 1994, nearly $60 \%$ were accounted for by energy use (NATCOM, I).

\section{Conclusion}

The complexities of nature and the feedback mechanism both positive and negative spread through time and space, are difficult to gauge, therefore the policies are made in the shadow of high degree of cascading uncertainties. For this reason "precaution" should serves as one the early guiding principle in elucidating the climate change policy. And enhancing mitigative capacity can be policy objective in itself. Policy should be developed to remove the present inequalities emanating from the climate change crisis. Such policies have ancillary benefits too. At global forums the rich nations should leave behind the baggage of the Plutocratic attitude and come forward for some ethical dialogue for the welfare of the humanity. A prolonged concerted action from nations is imperative. Efficiency, equity, and sustainability should be the main drivers of such an effort. Reduction measures tuned to the capabilities of the respective country and the technological advancement is required to cope with this challenge.

\section{References}

Arrhenius, S. (1896). Influence of carbonic acid in the air upon the temperature of the ground. Philosophical magazine and journal of Science. 41, No.251, 1986-92.

Ball, S.W. (1987). Choosing between choice models of ethics: Rawalsian equality, utilitarianism and the concept of persons. Netehrlands: Springer.

Benton, M. J. (2003). When Life Nearly Died: The Greatest Mass Extinction of All Time. London: Thames and Hudson.

Callendar, G.S. (1938). The Artificial Production of Carbon Dioxide and Its Influence on Climate. Quarterly J. Royal Meteorological Society. 64, 223-40. http://dx.doi.org/10.1002/qj.49706427503

Cavallo, Alfred J. (2004). Hubbert's Petroleum Production Model: An Evaluation and Implications for World Oil Production Forecasts. Natural Resources Research. 13, No. 4, 211-221. http://dx.doi.org/10.1007/s11053-004-0129-2

Dale, Jamieson. (1996). Ethics and Intentional Climate Change. Journal Climatic Change. 33 No3, 323-336. http://dx.doi.org/10.1007/BF00142580

Errington, P.L. (1948). In Appreciation of Aldo Leopold. The Journal of Wildlife Management. 12, No 4, 341-350.

Fourier, Joseph (1878). The Analytical Theory of Heat. UK:Cambridge University Press. (reissued by Cambridge University Press, 2009). 
Garrett, Hardin. (1968). The Tragedy of the Commons. Science. 162, No. 3859, 1243-1248. http://dx.doi.org/10.1126/science.162.3859.1243

Hallam \& Wignall, P. B. (1997). Mass Extinctions and Their Aftermath, Oxford: Oxford University Press.

Hartwick, J M. (1977). Intergenerational Equity and the Investing of Rents from Exhaustible Resources. American Economic Review. 67, No 5, 972-974.

Hensen, J. (1988). The greenhouse effect: impacts on current global temperature and regional heat waves. New York: Statement NASA Goddard Institute for space studies.

Hulburt, E.O. (1931). The Temperature of the Lower Atmosphere of the Earth. Physical Review. 38, 1876-90. http://dx.doi.org/10.1103/PhysRev.38.1876

IPCC. (1997). JT Houghton, LG Meira Filho, DJ Griggs and K Maskell (Eds).Stabilization of Atmospheric Greenhouse Gases: Physical, Biological and Socio-economic Implications, IPCC Technical Paper III - February 1997, Geneva, Switzerland. pp 52. Available: http://www.ipcc.ch/publications_and_data/publications_and_data_reports.shtml, (September 2011).

IPCC. (1990). The 1990 report of the IPCC Impacts Assessment Working Group. Available: http://www.ipcc.ch/publications_and_data/publications_and_data_reports.shtml, (July 2011).

IPCC. (1996). Impacts, Adaptations, and Mitigation of Climate Change: Scientific-Technical Analyses. Contribution of Working Group II to the Second Assessment Report of the Intergovernmental Panel on Climate Change. Cambridge University Press, Cambridge, United Kingdom and New York, NY, USA. Available: http://www.ipcc.ch/publications_and_data/publications_and_data_reports.shtml, (July 2011).

IPCC. (2007). Climate Change 2007: Mitigation of Climate Change. Contribution of Working Group III to the Fourth Assessment Report of the Intergovernmental Panel on Climate Change, 2007B. Metz, O.R. Davidson, P.R. Bosch, R. Dave, L.A. Meyer (eds) Cambridge University Press, Cambridge, United Kingdom and New York, NY, USA. Available: http://www.ipcc.ch/publications_and_data/publications_and_data_reports.shtml, (September 2011).

Johansen, Inge. (2007). Ethics of Climate Change Exploring the principle of equal emission rights, Norwegian Academy of Technological Sciences NTVA. Available: http://www.ntva.no. (September 2009).

Lovell, J. (2007). Climate change to make one billion refugees-agency", Reuters. Available: http://in.reuters.com (May 2007).

Meadows, Donella H., Meadows, Dennis L., Randers, Jorgen., \& Behrens III, William W. (1972). The Limits to Growth. New York: Universe Books.

Mill, J.S. (1864). Utilitarianism, (2nd ed). Longman Green, London: Longman, Roberts, and 


\section{Macrothink \\ Environmental Management and Sustainable Development \\ ISSN 2164-7682 2012, Vol. 1, No. 1}

Green.

NATCOM I. (2009). Available: www.natcomindia.org/natcomreport.htm. (November 2009).

Radhakrishnan, Sarvepalli., \& Moore, Charles A. (1957). A Source Book in Indian Philosophy. UK: Princeton University Press.

Raup, D. M., \& Jr. Sepkoswki, J. J. (1982). Mass extinctions in the marine fossil record. Science. 215, 1501-1503. http://dx.doi.org/10.1126/science.215.4539.1501,

PMid:17788674

Tyndall, John (1861). On the Absorption and Radiation of Heat by Gases and Vapours. Philosophical Magazine. ser. 4 (22), 69-94, 273-85.

Voula, Tsouna (2008). The Epistemology of the Cyrenaic School, UK: Cambridge University Press.

Zedillo, E. (2008). Global Warming: looking beyond Kyoto. Virginia: .R.R Donnelley Harrisonburg.

\section{Appendix}

Appendix 1: www.unhcr.org/publ/PUBL/3d58e13b4.pdf: Handbook on Procedures and Criteria for Determining Refugee Status under the 1951 Convention and the 1967 Protocol relating to the Status of Refugees- According to Article 1 A (2) of the 1951 Convention the term "refugee" shall apply to any person who:

"As a result of events occurring before 1 January 1951 and owing to well founded fear of being persecuted for reasons of race, religion, nationality, membership of a particular social group or political opinion, is outside the country of his nationality and is unable or, owing to such fear, is unwilling to avail himself of the protection of that country; or who, not having a nationality and being outside the country of his former habitual residence as a result of such events, is unable or, owing to such fear, is unwilling to return to it.

\section{Copyright Disclaimer}

Copyright reserved by the author(s).

This article is an open-access article distributed under the terms and conditions of the Creative Commons Attribution license (http://creativecommons.org/licenses/by/3.0/). 